International Journal of Agricultural Science and Research (IJASR)

ISSN (P): 2250-0057; ISSN (E): 2321-0087

Vol. 11, Issue 1, Feb 2021, 21-30

(C) TJPRC Pvt. Ltd.

\title{
PRICE SPREAD OF GUAVA IN MADURAI DISTRICT OF TAMIL NADU
}

\section{E. DHIVAGARAN ${ }^{* 1}$, S. SELVANAYAKI ${ }^{2} \&$ D. MURUGANANTHI ${ }^{3}$}

${ }^{I} P G$ Scholar, Department of Agricultural and Rural Management, Tamil Nadu Agricultural University, Coimbatore, Tamil Nadu, India

${ }^{2}$ Assistant Professor, Department of Agricultural and Rural Management, Forest College and Research Institute, Mettupalayam,

Tamil Nadu, India

${ }^{3}$ Assistant Professor, Department of Agricultural and Rural Management, Tamil Nadu Agricultural University, Coimbatore,

Tamil Nadu, India

\section{ABSTRACT}

Guava (Psidium gujava L.) belongs to the family, Myrtaceae. It is believed that guava was originated from the area extending from Southern Mexico or Central America (Morton, 1987) and it is extensively grown in both tropical and sub-tropical regions. Although this fruit is grown all over the world, India tops the global production followed by Pakistan, China and Brazil. However, in India, it is cultivated mainly for local consumption with minimal processing. Thus, the value chain of guava remains highly untapped. Madurai is one of the important guava producing districts in Tamil Nadu with various marketing channels. Present study was conducted on the price spread of guava in Madurai district during 2019-20. Samples for the study namely, producers and market intermediaries were selected using random sampling technique. The necessary data was acquired through personal interview with the help of pre-tested interview schedule. It was inferred from the study that there are six predominant marketing channels present in the study area.Results of analysis showed that out of the six channels, Channel II: Producer - Commission Agent - Retailer Consumer was the most efficientwith 28.60 per cent price spread and 71.40 per cent of producer's share in consumer's Rupee

KEYWORDS: Guava, Value chain, Marketing channel, Price spread, Producer's share in consumer's Rupee

Received: Dec 18, 2020; Accepted: Jan 08, 2021; Published: Jan 23, 2021; Paper Id.: IJASRFEB20213

\section{INTRODUCTION}

Guava (Psidium gujava L.) belongs to the family, Myrtaceae. It is believed that guava was originated from the area extending from Southern Mexico or Central America (Morton, 1987) and it is extensively grown in both tropical and sub-tropical regions. It was also well known for its traditional therapeutic benefits for diabetes, gut infection and metabolic disorder and obesity. Although this fruit was grown all over the world, India tops the global production followed by Pakistan, China and Brazil. The annual production of guava in India was around 4 million tonnes (Horticulture Statistics at a Glance, 2018). However the fruit was cultivated mainly for local consumption with minimal processing. The value chain of guava also remains highly untapped. In Tamil Nadu the area under guava was 9.69 thousand hectares and it produced 155.06 metric tonnes of guava (Horticulture Statistics at a Glance, 2018). Even though, Dindigul district stands first in production followed by Madurai, Madurai district leads in productivity (12.89 per cent) when compared with Dindigul district (9.36 per cent) (Horticulture Statistics at a Glance, 2018). Also, Madurai has good transport connectivity via all means that facilitates various marketing channels for guava. Hence the study was conducted to trace the available predominant marketing channels and to track the 
most efficient channel.

\section{MATERIALS AND METHODS}

Multi-stage sampling was used purposively to select the producers from the area under higher guava cultivation i.e., district, blocks, villages and producers. The intermediates were selected by simple random sampling technique. The survey area consists of two blockswith six villages each.Athanoor, Ayyur, Devaseri, Eirampatti, Muduvarpatti, and Vellayampatti villages were selected from Alanganallur block and Chinnapoolampatti, Karaikeni Kilankulam, Silarpatti, Vaiyur and Vannuvelampatti villages were selected from T. Kallupatti block. Five farmers were selected from each village resulting in sixty samples.Totally, sixty intermediaries were selected for the study including twenty commission agents, fifteen local traders, twenty retailers and five exporters.

Through personal interview method data were collected with the help of pre-tested interview schedule. In few cases, the produce was transferred to the exporter for export to countries such as Malaysia, Maldives, Dubai and Sri Lanka. In such cases, the exporters were considered as the terminal option in the channel.

\section{RESULTS AND DISCUSSIONS}

The price spread among various channels were tabulated and discussed below.

\section{Marketing Channels}

In the study area, the harvested guava enters various marketing channels and the predominant channels are presented in Table 1.

Table 1: Marketing channels for Guava in Madurai District

\begin{tabular}{|c|c|c|c|c|}
\hline Channel I & : & Producer $\rightarrow$ Retailer & & $\rightarrow$ Consumer \\
\hline Channel II & : & Producer $\rightarrow$ Commission Agent & $\rightarrow$ Retailer & $\rightarrow$ Consumer \\
\hline Channel III & : & Producer $\rightarrow$ Commission Agent & $\rightarrow$ Local Trader $\rightarrow$ & Retailer $\rightarrow$ Consumer \\
\hline Channel IV & : & Producer $\rightarrow$ Local Trader & $\rightarrow$ Retailer & $\rightarrow$ Consumer \\
\hline Channel V & : & Producer $\rightarrow$ Commission Agent & $\rightarrow$ Local Trader & $\rightarrow$ Exporter \\
\hline Channel VI & : & Producer $\rightarrow$ Local Trader & & $\rightarrow$ Exporter \\
\hline
\end{tabular}

\section{Marketing Costs}

Marketing of the produce incurs costs such as picking cost, transport cost, packing cost, labour cost, etc. Those costs differ from one channel to another. The marketing costs incurred in various channels were tabulated as follows.

Table 2: Marketing cost of intermediaries in Channel I

Channel I: Producer $\longrightarrow$ Retailer $\longrightarrow$ Consumer

\begin{tabular}{|l|l|l|l|}
\hline S. No & Particulars & $\begin{array}{l}\text { Amount (Rupees } \\
\text { per kg) }\end{array}$ & $\begin{array}{l}\text { Percentage } \\
\text { consumer's Rupee }\end{array}$ \\
\hline $\mathbf{1}$ & Producer & & \\
\hline & Gross price received & 23.00 & 51.11 \\
\hline
\end{tabular}




\begin{tabular}{|l|l|l|l|} 
& Picking & 0.50 & \\
\hline & Net price received & 22.50 & \\
\hline $\mathbf{2}$ & Retailer & & \\
\hline & Purchase price & 23.00 & \\
\hline & Loading and unloading & 1.00 & 2.22 \\
\hline & Marketing cost & 0.50 & 1.11 \\
\hline & Transport & 2.50 & 5.56 \\
\hline & Margin & 18.00 & 40.00 \\
\hline & Sale price & 45.00 & \\
\hline & Price paid by customer & $\mathbf{4 5 . 0 0}$ & $\mathbf{1 0 0 . 0 0}$ \\
\hline
\end{tabular}

From the Table 2, it is observed that the transportation cost is incurred by the retailer. The retailer procures the produce from the farmer's field. Since the retailer was able to procure from the farmer's field, he has the upper hand in deciding the price. Also, the retailer enjoys good share of margin when selling in the market. Even though the consumer Rupee was less when compared to other channels, the retailer reaps the maximum benefit in this channel. The producer's share in consumer's Rupee is $(50.00 \%)$

Table 3: Marketing cost of intermediaries in Channel II
Channel II: Producer
Commission Agent
Retailer
$\longrightarrow$ Consumer

\begin{tabular}{|c|c|c|c|}
\hline S. No & Particulars & Amount (Rupees per kg) & $\begin{array}{ll}\begin{array}{l}\text { Percentage } \\
\text { consumer's Rupee }\end{array} & \text { to } \\
\end{array}$ \\
\hline \multirow[t]{6}{*}{1} & Producer & & \\
\hline & Gross price received & 37.00 & 74.00 \\
\hline & Picking & 0.50 & \\
\hline & Loading and unloading & 0.40 & \\
\hline & Transport & 0.40 & \\
\hline & Net price received & 35.70 & \\
\hline \multirow[t]{7}{*}{2} & Commission Agent & & \\
\hline & Purchase price & 37.00 & \\
\hline & Packaging & 0.50 & 1.00 \\
\hline & marketing & 0.80 & 1.60 \\
\hline & Subtotal & 38.30 & \\
\hline & Margin & 3.70 & 7.40 \\
\hline & Sale price & 42.00 & \\
\hline \multirow[t]{7}{*}{3} & Retailer & & \\
\hline & Purchase price & 42.00 & \\
\hline & Loading and unloading & 0.20 & 0.40 \\
\hline & Transport cost & 0.80 & 1.60 \\
\hline & Margin & 7.00 & 14.00 \\
\hline & Sale price & 50.00 & \\
\hline & Price paid by the Consumer & $\mathbf{5 0 . 0 0}$ & 100.00 \\
\hline
\end{tabular}


From the Table 3, it is observed that the transportation cost was incurred by the producer and the retailer only, exposing the fact that the commission agent remains in a place facilitating the marketing activity where the producers and local traders meet. The producer's share in consumer's Rupee is $(71.40 \%)$

Table 4: Marketing cost of intermediaries in Channel III

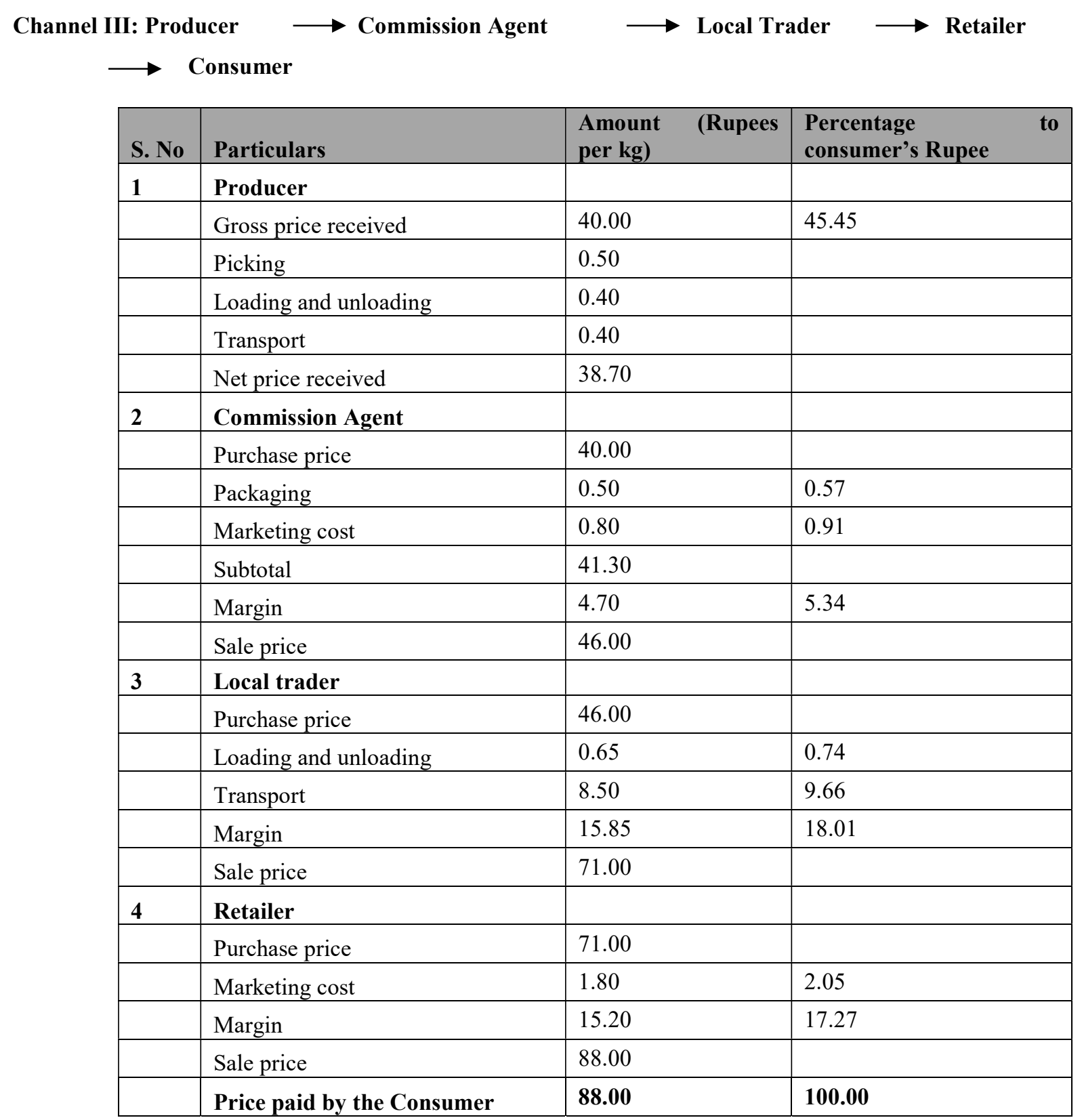

From Table 4, it is evident that the producers and the local traders were the ones who incur transportation cost revealing that the retailers were provided with the produce by the traders. In this channel the higher price was due to the reason of higher distance value addition, i.e., the produce was moved to Kerala for marketing.The producer's share in consumer's Rupee is $(43.98 \%)$ 
Table 5: Marketing cost of intermediaries in Channel IV

Channel IV: Producer $\longrightarrow$ Local Trader $\longrightarrow$ Retailer $\longrightarrow$ Consumer
\begin{tabular}{|l|l|l|l|}
\hline $\begin{array}{l}\text { S. } \\
\text { No }\end{array}$ & Particulars & $\begin{array}{l}\text { Amount } \\
\text { per kg) }\end{array}$ & $\begin{array}{l}\text { Percentage to } \\
\text { consumer's } \\
\text { Rupee }\end{array}$ \\
\hline $\mathbf{1}$ & Producer & & \\
\hline & Gross price received & 34.00 & 59.65 \\
\hline & Picking & 0.50 & \\
\hline & Net price received & 33.50 & \\
\hline $\mathbf{2}$ & Local trader & & 1.14 \\
\hline & Purchase price & 34.00 & 2.19 \\
\hline & Loading and unloading & 0.65 & 15.96 \\
\hline & Transport & 1.25 & \\
\hline & Margin & 9.10 & \\
\hline & Sale price & 45.00 & \\
\hline $\mathbf{3}$ & Retailer & & 17.16 \\
\hline & Purchase price & 45.00 & \\
\hline & Marketing cost & 1.80 & \\
\hline & Margin & 57.00 & $\mathbf{1 0 0 . 0 0}$ \\
\hline & Sale price & & \\
\hline & Price paid by the Consumer & $\mathbf{5 7 . 0 0}$ & \\
\hline
\end{tabular}

From the Table 5, we could observe that the local trader was the one connecting the retailer and producer neglecting the commission agent. The producer's share in consumer's Rupee is $(58.77 \%)$

Table 6: Marketing cost of intermediaries in Channel V

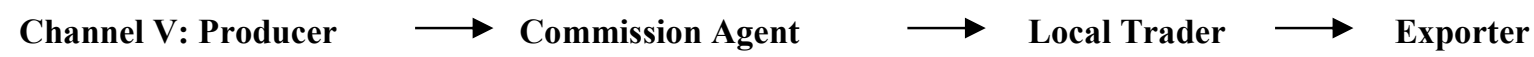

\begin{tabular}{|c|c|c|c|}
\hline $\begin{array}{l}\text { S. } \\
\text { No }\end{array}$ & Particulars & $\begin{array}{l}\text { Amount } \\
\text { per kg) }\end{array}$ & $\begin{array}{ll}\begin{array}{l}\text { Percentage } \\
\text { importer's Rupee }\end{array} & \text { to } \\
\end{array}$ \\
\hline \multirow[t]{6}{*}{1} & Producer & & \\
\hline & Gross price received & 32.00 & 13.91 \\
\hline & Picking & 0.50 & \\
\hline & Loading and unloading & 0.40 & \\
\hline & Transport & 0.40 & \\
\hline & Net price received & 30.70 & \\
\hline \multirow[t]{6}{*}{2} & Commission Agent & & \\
\hline & Purchase price & 32.00 & \\
\hline & Packaging & 0.50 & 0.22 \\
\hline & Marketing cost & 0.80 & 0.35 \\
\hline & Subtotal & 33.30 & \\
\hline & Margin & 3.70 & 1.61 \\
\hline
\end{tabular}




\begin{tabular}{|c|c|c|c|}
\hline & Sale price & 37.00 & \\
\hline \multirow[t]{6}{*}{3} & Local trader & & \\
\hline & Purchase price & 37.00 & \\
\hline & Loading and unloading & 0.65 & 0.28 \\
\hline & Transport & 0.90 & 0.39 \\
\hline & Margin & 3.45 & 1.50 \\
\hline & Sale price & 42.00 & \\
\hline \multirow[t]{11}{*}{4} & Exporter & & \\
\hline & Purchase price & 42.00 & \\
\hline & Packing cost & 3.00 & 1.30 \\
\hline & Transport & 6.00 & 2.61 \\
\hline & Labour cost & 2.00 & 0.87 \\
\hline & Damage loss & 4.20 & 1.83 \\
\hline & Exporting cost & 80.00 & 34.78 \\
\hline & Subtotal & 137.20 & 59.65 \\
\hline & Margin & 92.80 & 40.35 \\
\hline & Sale price & 230.00 & \\
\hline & Price paid by the importer & 230.00 & 100.00 \\
\hline
\end{tabular}

From the Table 6, it is evident that the price spread was higher in this channel because of the exporting activity. Here the exporter was enjoying the higher percentage of margin. The producer's share in importer's Rupee is (13.35\%)

Table 7: Marketing cost of intermediaries in Channel VI

Channel VI: Producer Local Trader $\longrightarrow$ Exporter

\begin{tabular}{|c|c|c|c|}
\hline $\begin{array}{l}\text { S. } \\
\text { No }\end{array}$ & Particulars & $\begin{array}{l}\text { Amount } \\
\text { per kg) }\end{array}$ & $\begin{array}{ll}\text { Percentage } & \text { to } \\
\text { importer's Rupee }\end{array}$ \\
\hline \multirow[t]{4}{*}{1} & Producer & & \\
\hline & Gross price received & 34.00 & 14.78 \\
\hline & Picking & 0.50 & \\
\hline & Net price received & 33.50 & \\
\hline \multirow[t]{6}{*}{2} & Local trader & & \\
\hline & Purchase price & 34.00 & \\
\hline & Loading and unloading & 0.65 & 0.28 \\
\hline & Transport & 0.90 & 0.39 \\
\hline & Margin & 6.45 & 2.80 \\
\hline & Sale price & 42.00 & \\
\hline \multirow[t]{6}{*}{3} & Exporter & & \\
\hline & Purchase price & 42.00 & \\
\hline & Packing cost & 3.00 & 1.30 \\
\hline & Transport & 6.00 & 2.61 \\
\hline & Labour cost & 2.00 & 0.87 \\
\hline & Damage loss & 4.20 & 1.83 \\
\hline
\end{tabular}




\begin{tabular}{|l|l|l|l|}
\hline & Exporting cost & 80.00 & 34.78 \\
\hline & Subtotal & 137.20 & 59.65 \\
\hline & Margin & 92.80 & 40.35 \\
\hline & Sale price & 230.00 & \\
\hline & Price paid by the importer & $\mathbf{2 3 0 . 0 0}$ & $\mathbf{1 0 0 . 0 0}$ \\
\hline
\end{tabular}

From the Table 7, we could observe that it is not much different from the previous marketing channel that only the commission agent was neglected by the trader so that he could get produce for less price. The producer's share in importer's Rupee is $(14.57 \%)$

Table 8: Price spread of guava $(\mathrm{Rs} / \mathrm{Kg})$

\begin{tabular}{|c|c|c|c|c|c|c|c|}
\hline $\begin{array}{l}\text { S. } \\
\text { No }\end{array}$ & Particulars & Channel I & $\begin{array}{l}\text { Channel } \\
\text { II }\end{array}$ & Channel III & Channel IV & Channel V & $\begin{array}{l}\text { Channel } \\
\text { VI }\end{array}$ \\
\hline \multirow[t]{7}{*}{1} & Producer & & & & & & \\
\hline & Gross price received & 23.00 & 37.00 & 40.00 & 34.00 & 32.00 & 34.00 \\
\hline & & $(51.11)$ & $(74.00)$ & $(45.45)$ & $(59.65)$ & $(13.91)$ & $(14.78)$ \\
\hline & Marketing cost & 0.50 & 1.30 & 1.30 & 0.50 & 1.30 & 0.50 \\
\hline & & $(1.11)$ & $(2.60)$ & $(1.48)$ & $(0.88)$ & $(0.57)$ & $(0.22)$ \\
\hline & Net price & 22.50 & 37.50 & 38.70 & 33.50 & 30.70 & 33.50 \\
\hline & & $(50.00)$ & $(71.40)$ & $(43.98)$ & $(58.77)$ & $(13.35)$ & $(14.57)$ \\
\hline \multirow[t]{9}{*}{2} & Commission Agent & & & & & & \\
\hline & Price paid & - & 37.50 & 40.00 & - & 32.00 & - \\
\hline & & & $(74.00)$ & $(45.45)$ & & $(13.91)$ & \\
\hline & Marketing cost & - & 1.30 & 1.30 & - & 1.30 & - \\
\hline & & & $(2.6)$ & $(1.48)$ & & $(0.57)$ & \\
\hline & Marketing margin & - & 3.70 & 4.70 & - & 3.70 & - \\
\hline & & & $(7.40)$ & $(5.34)$ & & $(1.61)$ & \\
\hline & Price received & - & 42.00 & 46.00 & - & 37.00 & - \\
\hline & & & $(84.00)$ & $(52.27)$ & - & $(16.09)$ & - \\
\hline \multirow[t]{9}{*}{3} & Local Trader & & & & & & \\
\hline & Price paid & - & - & 46.00 & 34.00 & 37.00 & 34.00 \\
\hline & & & & $(52.27)$ & $(59.65)$ & $(16.09)$ & $(14.78)$ \\
\hline & Total marketing cost & - & - & 9.15 & 1.90 & 1.55 & 1.55 \\
\hline & & & & $(10.40)$ & $(3.33)$ & $(0.67)$ & $(0.67)$ \\
\hline & Marketing margin & - & - & 15.85 & 9.10 & 3.45 & 6.45 \\
\hline & & & & $(18.01)$ & $(15.96)$ & $(1.50)$ & $(2.80)$ \\
\hline & Price received & - & - & 71.00 & 45 & 42.00 & 42.00 \\
\hline & & & & $(80.68)$ & $(78.95)$ & $(18.26)$ & $(18.26)$ \\
\hline \multirow[t]{2}{*}{4} & Retailer & & & & & & \\
\hline & Price paid & 23.00 & 42.00 & 71.00 & 45 & - & - \\
\hline
\end{tabular}




\begin{tabular}{|c|c|c|c|c|c|c|c|}
\hline & & $(51.11)$ & $(84.00)$ & $(80.68)$ & $(78.95)$ & & \\
\hline & Total marketing cost & 4.00 & 1.00 & 1.80 & 1.80 & - & - \\
\hline & & $(8.89)$ & $(2.00)$ & $(2.05)$ & $(3.16)$ & & \\
\hline & Marketing margin & 18.00 & 7.00 & 15.20 & 10.20 & - & - \\
\hline & & $(40.00)$ & $(14.00)$ & $(17.27)$ & $(17.89)$ & & \\
\hline & Price received & 45.00 & 50.00 & 88.00 & 57.00 & - & - \\
\hline & & $(100.00)$ & $(100.00)$ & $(100.00)$ & $(100.00)$ & & \\
\hline \multirow[t]{16}{*}{5} & Exporter & & & & & & \\
\hline & Price paid & - & - & - & - & 42.00 & 42.00 \\
\hline & & & & & & $(18.26)$ & $(18.26)$ \\
\hline & Total marketing cost & - & - & - & - & 95.20 & 95.20 \\
\hline & & & & & & $(41.39)$ & $(41.39)$ \\
\hline & Marketing margin & - & - & - & - & 92.80 & 92.80 \\
\hline & & & & & & $(40.35)$ & $(40.35)$ \\
\hline & Price received & - & - & - & - & 230.00 & 230.00 \\
\hline & & & - & - & - & $(100.00)$ & $(100.00)$ \\
\hline & Price spread & 22.50 & 14.30 & 49.30 & 23.50 & 199.30 & 196.50 \\
\hline & & $(50.00)$ & $(28.60)$ & $(56.02)$ & $(41.23)$ & $(86.65)$ & $(85.43)$ \\
\hline & $\begin{array}{l}\text { Total marketing cost } \\
\text { of the Channel }\end{array}$ & 4.50 & 3.60 & 13.55 & 4.20 & 99.35 & 97.25 \\
\hline & & $(10.00)$ & $(6.08)$ & $(15.41)$ & $(7.37)$ & $(43.20)$ & $(42.28)$ \\
\hline & $\begin{array}{l}\text { Total marketing } \\
\text { margin }\end{array}$ & 18.00 & 10.70 & 35.75 & 19.30 & 99.95 & 99.25 \\
\hline & & $(40.00)$ & $(21.40)$ & $(40.62)$ & $(33.85)$ & $(43.46)$ & $(43.15)$ \\
\hline & $\begin{array}{l}\text { Producer's share in } \\
\text { consumer's Rupee (\%) }\end{array}$ & $(50.00)$ & $(71.40)$ & (43.98) & $(58.77)$ & $(13.35)$ & (14.57) \\
\hline
\end{tabular}

(Figure in parenthesis indicates percentage to consumer or importer price)

\section{Price Spread}

It is evident from the Table 8 that the Channel II was having less price spread viz., Rs. $14.30 / \mathrm{kg}(28.60 \%$ of the price paid by the consumer). In this Channel there were only two intermediates involved and the producer's share in consumer Rupee was also (71.4\%) higher than the other Channels. The total marketing cost was Rs. 3.60/kg (6.08\%) and marketing margin was Rs.10.70/kg (21.40\%). The next best Channel would be Channel IV with the price spread of Rs. 23.50/kg (41.23\% of the price paid by the consumer). The marketing cost was Rs. 4.20/kg (7.37\%) and margin was Rs. 19.30/kg (33.85\%). Channel I may look like having less price spread in terms of Rs/kg (Rs. 22.50/kg) when compared to Channel IV (Rs.23.50/kg), but the per cent spread of Channel I was higher(50.00\%) than the Channel IV(41.23\%). Also the producer's share in consumer Rupee was only Rs.22.50(50\%). The marketing cost and marketing margin were Rs. 4.50/kg (10.00\%) and Rs. 18/kg (40\%) respectively. In Channel III, the marketing cost, margin and price spread were Rs. 13.55/kg (15.41\%), Rs. $35.75 / \mathrm{kg}(40.62 \%)$ and Rs. $49.30 / \mathrm{kg}$ (56.02\%) respectively. The producer's share was Rs. 38.70/kg (43.98\%).

The Channel VI stands previous to the last with Rs. 97.25/kg (42.28\%), Rs. 99.25/kg (43.15\%) and Rs. 196.50/kg $(85.43 \%)$ as marketing cost, marketing margin and price spread respectively. The producer's share was Rs. $33.50 / \mathrm{kg}$ 
(14.57\%). The last effective chain was Channel V with Rs. 199.30/kg (86.65) as price spread, Rs. 99.35/kg (43.20\%) as marketing cost and Rs. $99.95 / \mathrm{kg}(43.46 \%)$ as margin with the producer's share of Rs. 30.70/kg (13.35\%).

\section{CONCLUSIONS}

It was concluded from the findingsthat Channel II was the efficient Channel where there were only two intermediates with higher efficiency. It may seem that the Channel I was efficient because of single intermediate-retailer. But the truth was, in that Channel the producer's share in consumer Rupee was less and the retailer exploits the actual market price and gets higher benefit. In general, it could also be seen that the commission agent facilitates ground for the producers to sell their produce and the local traders mostly involve in transporting the produce from area of supply to the area of demand. In neglecting the local trader, the retailer has to arrange his own transport for moving the produce which shows that the transportation was in negligible and the transportation cost was also higher. Also from the study, it was evident that there were no guava processing plants in Madurai. It could be suggested that the guava farmers can form an organization so that they can have their own ground for marketing the produce to the retailers and customers as a whole where the intermediaries can be avoided and their profit can be increased. The guava processing unit can also be established by the farmer organization so that the value of the product and the profit can be increased by tapping the underutilized opportunity of fruit processing.

\section{REFERENCES}

1. Singh, S. P. (2011). Guava (Psidium guajava L.). In Postharvest biology and technology of tropical and subtropical fruits (pp. 213-246e). Woodhead Publishing.

2. Omayio, D. G., Abong, G. O., Okoth, M. W., Gachuiri, C. K., \& Mwang'ombe, A. W. (2019). Current Status of Guava (Psidium Guajava L) Production, Utilization, Processing and Preservation in Kenya: A Review. Current Agriculture Research Journal, 7(3), 318-331.

3. PACHPOR, NITESH, et al. "A COMPARATIVE ANALYSIS OF THE PERFORMANCE OF NATURAL AND FORCED CONVECTION SOLAR DRYER FOR DRYING FRUITS." International Journal of Agricultural Science and Research (IJASR) 8.6, Dec 2018, 89-94

4. Komaravel, S. Value chain analysis of tapioca in western parts of Tamil Nadu (Doctoral dissertation, TAMIL NADU AGRICULTURAL UNIVERSITY COIMBATORE).

5. Glance, H. S. A. A. (2018). Horticulture Statistics Division Department of Agriculture. Cooperation \& Farmers' Welfare Ministry of Agriculture and Farmers' Welfare Government of India.

6. De, LAKSHMAN CHANDRA. "Citrus rejuvenation in NE region of India." International Journal of Agricultural Science and Research 7.2 (2017): 325-342.

7. Acharya, S. S. (2004). Agricultural Marketing In India, 4/E. Oxford and IBH publishing.

8. Manivenkatesh, K. S., Selvanayaki, S., Devi, M. N., \& Pandiyan, M. (2020). Value chain analysis of jasmine in Madurai district of Tamil Nadu. International Journal of Farm Sciences, 10(1), 6-12.

9. Kamble, S. H., Shelke, R. D., \& Devika, D. (2017). Price spread of finger millet (Ragi) in Dharmapuri district of Tamil Nadu. Trends in Biosciences, 10(25), 5276-5279. 
10. Sridhar, N., and S. Poongothai. "DELINEATION OF GROUNDWATER POTENTIAL ZONES IN LOWER PONNAIYAR RURAL WATERSHED, CUDDALORE DISTRICT, TAMILNADU, INDIA." International Journal of Civil Engineering (IJCE) 6.1, Dec - Jan 2017; 15-26

11. Venkannanvara, M. M., Gaddi, G. M., \& Gracy, C. P. (2019). Growth Performance and Marketing of Maize in Karnataka, India. Int. J. Curr. Microbiol. App. Sci, 8(10), 380-387.

12. Balaji, P. P., \& Sivakumar, N. R. (2001). Marketing channels of ground nut grown in Tiruvanamalai district of Tamil Nadu. Indian Journal of Agricultural Marketing15, 2, 55-59.

13. Naphade, S. A., \& Tingre, A. S. (2008). Economics of production and marketing of guava in Buldhana district of Maharashtra. Indian Journal of Agricultural Marketing, 22(2), 32-41. 